\title{
Tarihsel Düşüncede Avrupamerkezci Söylemin "Hegemonya" İdeografisi
}

\author{
Rameş Rzayev*
}

(ORCID ID: 0000-0001-9699-8116)

\author{
Makale Gönderim Tarihi \\ 04.05.2021
}

Makale Kabul Tarihi

25.09.2021

\section{Atıf Bilgisi/Reference Information}

Chicago: Rzayev, R., "Tarihsel Düşüncede Avrupamerkezci Söylemin "Hegemonya" İdeografisi", Vakanüvis-Uluslararası Tarih Araştırmaları Dergisi, 6/2 (2021): 786-816.

APA: Rzayev, R. (2021). Tarihsel Düşüncede Avrupamerkezci Söylemin "Hegemonya" İdeografisi. Vakanüvis-Uluslararası Tarih Araştırmaları Dergisi, 6 (2) , 786-816.

\section{Öz}

Doğu ile Batı kutuplaşmasının doğasına dair varsayımların temelinde yatan ideolojik tefrikler basit bir çatışmanın yansıması değildir. "Avrupamerkezcilik" ibaresi temelinde kurgulanan Doğu ile Batı arasındaki ayrımcılığı Antonio Gramsci'nin "hegemonya" kategorisi ve Michel Foucault'nun "bilgi-güç" denklemi etrafında sorgulamak, bilmediğimiz birçok algı biçimini ortaya çıkmaktadır. Bir görüş ve temsil makamı doğrultusunda şekillenen "Avrupamerkezcilik" kavramı genelde ötekinin varlığı ile çatışarak kendisini tanımlamaktadır. Bu çalışmada, Avrupamerkezciliğin tarihsel boyutu ele alınarak hem kendi söylemi hem de "öteki"ni inşa etme noktasındaki prosedürel karakteri tahlil edilmektedir. Aydınlanma süreci ile yeni bir ivme kazanan "Avrupamerkezcilik" söylemi, Batı-dışı toplumların sosyal-kültürel ve siyasi-ekonomik hayatlarını modernleşme temelinde "yeniden üreterek" stratejiler oluşturması, tarihsel düşünceyi bizatihi formüle edebilme özelliği ile

* Dr. Öğretim Üyesi. Bakü Avrasya Üniversitesi, Sosyal Bilimler Bölümü, Azerbaycan, ramesrza@gmail.com.

Assist. Prof. Dr., Eurasian University of Baku Department of Social Sciences, Azerbaijan.

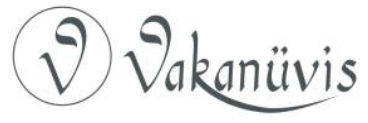


ilgilidir. Genel itibariyle Batı-dışı toplumların siyasal, ekonomik, sosyal ve kültürel hayatlarını "tek tipli" şekilde düzene sokma açısından fenomenal nitelik taşıdığı çözülmesi gereken bir sorundur. Söz konusu toplumların yaşam biçimi algısında özden uzaklaşma kaygısı tarihsel gerçeklik itibariyle salt hegemonya alanı içinde tatmin noktasına indirgendiğini doğru saptamalarla ayırt etmek mümkün olabilir.

Anahtar Kelimeler: Avrupamerkezcilik, Aydınlanma, Doğu-Batı, Oryantalizm, Hegemonya

\section{Historical Thought-Oriented Eurocentrism Is In Discourse "Hegemony" Ideography}

\section{Abstract}

The ideological distinctions that underlie the assumptions about the nature of the East and West polarization are not simply a reflection of the conflict. Questioning the discrimination between East and West based on the phrase "Eurocentrism" around Antonio Gramsci's "hegemony" category and Michel Foucault's "knowledge-power" equation reveals many forms of perception that we do not know. The concept of "Eurocentrism" shaped in the direction of an opinion and representation authority generally defines itself in conflict with the existence of the other. In this study, by considering the historical dimension of Eurocentrism, both its own discourse and its procedural character at the point of constructing the "other" are analyzed. The discourse of "Eurocentrism", which gained a new momentum with the Enlightenment process, is related to the social-cultural and political-economic life of non-Western societies by "reproducing" strategies on the basis of modernization, and the ability to formulate historical thought itself. It should be stated that, in general, non-Western societies have a phenomenal nature in order to organize their political, economic, social and cultural lives in a "uniform" way. It can be said that the anxiety of detachment from the essence in the perception of life style of the aforementioned societies is distinguished by correct determinations that, in terms of historical reality, it has been reduced to satisfaction within the realm of hegemony.

Keywords: Eurocentrism, Enlightenment, East-West, Orientalism, Hegemony

\section{Giriş}

Tarihi düşüncede "Avrupamerkezcilik" kavramı, egemen bir kültürün basit teorik ifadesi değil, karmaşık entelektüel faaliyetlerin

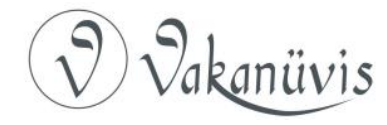


hareket noktasıdır. Batı'nın dünya üzerindeki tesiri bu olgu dizisinden biridir. Sorunu bu bağlamda ortaya koymak ciddi bir bölünmeyi görmek anlamına gelmektedir. Bu sorun içerisinde Batı'nın "farklı olmak hakkı ve eşitsiz gelişme savı"11 iki ana kutbun ayırt edilmesiyle belirginleşmektedir. Bir tarafta "Batı" öz varlığını belirli bir ayrıma istinaden "güç-bilgi" ${ }^{2}$ nosyonuna göndermede bulunarak formüle etmekte ve kendisini akademik bir disiplin içinde somutlaştırmaktadır. "Doğu" ise modernleşme sürecinden itibaren kendisine yabancılaşan varoluşunu anlamlandıramamanın kaygısı içine itilmektedir. Böylesine derin tefrikin herhangi bir toplumsal çevre, kültürel yapı ve siyasal örgütlenme biçimleri üzerindeki tesirleri "oryantalizm ve sömürgecilik söylemi"'3 araştırmalarında kendisini açık göstermektedir. Bu ikili karşıtlığın kültürel ve entelektüel problemlere dair temel metodolojik yaklaşımının "Batı ölçeğine göre kavramsallaştırılması"” sorgulanması gereken önemli bir husustur. Doğu'nun genel olarak en özgün yanları ve Batı'dan farklı tarihi çizgide değişimler geçirmesi İbni Haldun'un kitabında şöyle şerh edilmiştir:

"Bu bölgenin halkları yapılarında, huylarında, yaşamlarında ve tüm doğal durumlarında geçim, konut, sanat, bilim ve devlet gibi meseleler uygarlığa elverişli ölçülerde tesis edilmiştir. Bu halkalarda peygamberlik, mülk, devlet, şeriat hükümleri, bilimler, kentler, yapılar, bağlar-bahçeler ve üstün sanatlar başka halkalardan daha uygar durumdadır. ${ }^{15}$

Batı dünyasının paradigmatik yapısında Doğu'ya dair ortaya koyduğu temel sorunların nasıl varlık kazandığını? ilerlemeci tarih çizgisinde belirlenen hareket noktasının bu ayrım içindeki izahı nedir? Sorularına yanıt, Avrupamerkezciliğin başlangıç döneminden itibaren benimsedikleri tutum ve zihni yapılarında düğümlediklerini söylemek pek zor değildir. Tarihsel geçmişi geleceğe bağlamada önem taşıyan Avrupamerkezci kavramların bu varsayım üzerinde nasıl bina edildiği

\footnotetext{
1 Samir Amin, Avrupamerkezcilik: Bir Ideolojinin Eleştirisi, çev. Mehmet Sert, İstanbul, 2007, s. 20.

2 Jose Guilherme Merquior, Foucault, çev. Nurettin Elhüseyni, İstanbul, 1986, s. 132.

${ }^{3}$ Bryan S. Turner, Oryantalizm, Postmodernizm ve Globalizm, çev. İbrahim Kapaklıkaya, İstanbul, 2003, s. 17.

${ }^{4}$ Jack Goody, Tarih Hırsızlığı, çev. Gül Çağalı Güven, İstanbul, 2012, s. 2.

5 İbni Haldun, Mukaddime, C. 1, çev. Turan Dursun, Ankara, 1977, s. 221.
}

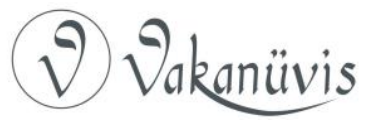


bir kopuş noktasına işaret etmektedir. Tarihi çerçevede Batı kendi medeniyetinin köklerini "Yahudi-Hristiyan, Grek-Roma veya Klasik gelenekler dâhil olmakla üzere iki kaynağa"6 dayandırdığı gerçeği bu bağlantıda saklıdır. Dördüncü yüzyılın başlarından itibaren ise Germen kavimlerinin Roma İmparatorluğu'nun sınırlarını aşan akınları Batı'nın tüm eylem istikâmetini daha da karmaşık hale getirmiştir. Dünya tarihini etkileyen süreç Batı'da kendine özgü dinamikleri siyasi, askeri ve ekonomik çıkarlara uygun "hegemonya"* alanlarına sessizce kaydırmıştır. Grek kültürü, Roma hukuku ve Hristiyan dini geleneklerine dayandırılan bu dünya görüşü 7. yüzyıldan itibaren İslam'ın yayılmasıyla “...Hristiyan Avrupa'yla Müslüman Asya arasındaki karşıtlığa dönüşmüş ve önceden kalma 'demokratik' ve 'despotik' yaftaları tevarüs ettirmiştir."” Söz konusu geleneğin dayandığı birikimden hareketle Ortaçağ Hristiyanlığının Protestan formülasiyonu içinde gerçekleştirilen Batılı (ahlak, sanat, özgürlük ve mülkiyet) kavramları Rönesans döneminin entelektüel çerçevesini çizmektedir. Batı'da toplumsal değişmeyi köklü bir biçimde etkilemiş Rönesans dönemi 16. ve 17. yüzyılların Reformasyon, Aydınlanma Çağı ve Sanayi Devrimi'ni üç aşamada (politik örgütlenme, ekonomik sistem ve kültürel yapı) belirgin hale getirmiştir. Bu dönüşümün toplumsal ve ekonomik güçleri, siyasal ve zihinsel araçları Batı'nın geri kalanını da değiştirmeye yetecek "teknolojinin, bilimin veya bireyci, laik, ilerlemeye inanan ussalcı ideoloji"8 ile özdeşleştiren modernleşme sürecini başlattığını söylemek mümkündür.

Modernleşme ile birlikte dünyaya biçim verecek olan köklü

\footnotetext{
${ }^{6}$ Alev Alatlı, Batı'ya Yön Veren Metinler Kökler/Orta Çağlar ( $\infty$-1350), C. 1, İstanbul, 2010, s. 3.

* "Hegemonya" kavramı - (etimoloji olarak Yunanca "hegemon" sözünden türemiş, önder, rehber, yönetici anlamına gelmektedir ) - siyasal, ekonomik, kültürel, ideolojik, ahlaki ve entelektüel üstünlüğü esas alan rızaya dayalı bir ilişki türüdür. Diğer bir deyişle "sivil toplum" ile "siyasal toplum", "rıza" ile "güç" arasındaki temas noktasıdır. Gramsci çözümlemelerinde "hegemonya" kavramı, bir sınıf ya da grubun diğer sınıflar üzerinde, bu unsurların aktif rızası ile kazandığı liderlik durumunu kategorize eden sınıflar arası bir ilişki biçimidir - Joseph A. Buttigieg (ed.), Antonio Gramsci: Hapishane Defterleri, C. 4, çev. Barış Baysal, İstanbul, 2014, s. 77.

7 Jack Goody, Tarih Hırsızı̆̆ı, çev. Gül Çağalı Güven, İstanbul, 2012, s. 72.

8 Eric Hobsbawm, Devrim Çağı: Avrupa 1789-1848, çev. Bahadır Sina Şener, Ankara, 2003, s. 11.
}

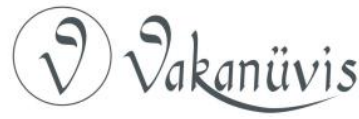


dönüşüm üç parametrede (kapitalizm, endüstriyalizm ve ulus-devlet) Avrupamerkezci teamülleri gerçekleştirmektedir. Bu noktada oluşturulması gereken siyasi-tarihsel kriterler diğer toplumlarda yeni örgütlenme biçimini ortaya çıkarmaktadır. "Avrupamerkezci" ideolojinin evrensellik boyutunu kapsayan bu parametreler "ilerlemeci dünya tarihinin aktif öznesi"g olarak tam bir paradigma oluşturmaktadır. Ideolojilerin çatıştığı asıl nokta ise burasıdır. Evrenselci bir paradigmanın anahtar kavramı halinde sunulan "Avrupamerkezci" kurguda Batı-dışı toplumların tarihi ve toplumsal gerçeklikleriyle bağdaşmayan tarafları vardır. Avrupa emperyalizminin diğer toplumların hayatında yol açtığı tahribatın ve karşı karşıya bıraktığı açmazın tam olarak bilincine varmak, değişiklik arayışının temel koşuludur. ${ }^{10}$ Çünkü modern dünyanın temsilcisi olarak Batı́nın dünyayı yeniden inşa etme çabası "hegemonyanın" ayırt edici unsurlarının kalıbı içinde olduğu yadsınamaz. Avrupamerkezciliğin karakterini ortaya koyan tarihsel ve entelektüel gerçeklikleri akademik anlamda "Oryantalizmin tarihi otoritesini"11 Batı'ya yarar bir biçimde ortaya çıkarmaktadır. Sorun rasyonel-entelektüel şemanın içinde bulunduğu "hegemonik" kavramlar ışı̆̆ında çözüme tabi tutulmaya çalışılmaktadır. Avrupamerkezci anlayış, paradigmatik ilişkiler temelinde çözümlenmediği sürece baskın pratik-eleştirel karakteri kendi krizini yaratacaktır. Bunun en belirgin göstergelerinden biri terminoloji meselesidir. Kapsadıkları olası anlamları en basit şekilde açıklayacak tabirlerin kasten müphem bırakılması sorunları çözme açısından yeterli derecede tercih edilir değildir.

\section{Avrupamerkezci Paradigmanın Genel Hatları}

Avrupamerkezcilik tarihinin bütünü içinde meydana gelen paradigmatik bükülmenin en önemli niteliği Aydınlanma'nın evrensel tasarısıyla düzen kimliğine bürünmüş olmasıdır. 18. yüzyıldan itibaren Batılı model çerçevesini şekillendiren Kartezyen felsefe bir dizi yeni tartışmaları gündeme getirmiştir. Toplumsal değişme üzerinde ilk etkisi eleştirel-ussal temelde seküler niteliği ortaya çıkarmıştır. Tarihi

\footnotetext{
9 John M. Hobson, Batı Medeniyetinin Doğulu Kökenleri, çev. Esra Ermert, İstanbul, 2015, s. 26.

${ }^{10}$ Amin, Avrupamerkezcilik: Bir Ideolojinin Eleştirisi, s. 180.

${ }^{11}$ Edward Said, Oryantalizm. çev. Nezih Uzel. İstanbul, 1998, s. 36.
}

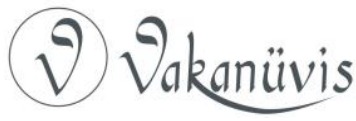


"ilerleme çizgisi"12 üzerinden kavrayan dönem düşünürleri Aydınlanma'yı yüceltmek için aşırı bir eğilim sergilemekten kaçınmamışlardır. ${ }^{13}$ Aydınlanma hareketinin gerçek taşıyıcılarının üç kuşaktan oluştuğu ve belirli bir disiplin içinde temel sorunları teşrih etmek yoluyla tartışmaya açtıkları bir gösterge olarak kabul edilmektedir. Birinci kuşağın temsilcileri Montesquieu ve Voltaire'in öncelikle yer aldığı, Newton ve Locke'un düşüncelerinin etkisiyle amaca dayalı faaliyetlere yönelen ikinci kuşak, Hume, Rousseau, Diderot ve d'Alembert'in düşünceleriyle Aydınlanma'ya belli bir perspektif kazandırmıştırlar. Üçüncü kuşağın temsilcileri Kant, Turgot ve d'Holbach tarafından Aydınlanma'nın temel problematiğini teşkil eden felsefi, epistemolojik, bilimsel ve siyasal sorunları yenidünya düzeninin disiplini şeklinde kavramsallaştırmışlardır. ${ }^{14}$ Bu nedenle, yeni çalışma yöntemleri için zaruri olan yeni alışkanlıkların kazanılması gerçekleşecektir. Üçüncü kuşağın entelektüel atılımı modern toplum tahayyülünü rasyonalite teorisiyle desteklemektedir. Böyle bir perspektif içinde disiplinli, kontrollü ve tek tipli toplum kurma hedefi hegemonya sorununa belirli bir kesinlik kazandırmaktadır.

Aydınlanma portresi içerisinde Immanuel Kant'ın 1784 yılında kaleme aldığı "Aydınlanma Nedir?" adlı makalesi başlıca yapıt olarak görülmektedir. Makalede insan etkinliğine asıl anlamını kazandıran sorunların "insanın kendi suçu ile düşmüş olduğu 'ergin olmama' durumundan kurtulması"15 ölçüt olarak hareket için bir koşul oluşturacaktır. Dünya tarihinin "özgürlük bilincine doğru ilerleme ve bilimsel, tarihsel, felsefi düşünceye yönelme" ${ }^{16}$ tanımı aslında Kant'a ait olsa da Hegel'in siyasal kuramında kurucu güç olarak "akıl ideası"17 gelenekle modernlik arasındaki karşıtlığa yön verecektir. Aydınlanmanın buradaki bilgi iddiası, aklı bir güç aracına yani otoriteye dönüştürmesidir. Bu düşüncenin Batı siyasetine sirayet eden teorik

\footnotetext{
12 Anthony Giddens, Sosyoloji, çev. Zeynep Mercan, İstanbul, 2012, s. 152.

${ }^{13}$ Frederick Copleston, Felsefe Tarihi, C. 7, çev. Aziz Yardımlı, İstanbul, 2004, s. 209.

${ }^{14}$ Ahmet Çiğdem, Aydınlanma Düşüncesi, İstanbul, 1993, s. 17.

15 Mehmet Ali Ağaoğulları (ed.), Sokrates'ten Jakobenlere: Batı'da Siyasal Düşünceler, İstanbul, 2015, s. 519.

${ }^{16}$ Robin G. Gollingwood, Tarih Tasarımı, çev. Kurtuluş Dinçer, İstanbul, 1990, s. 123.

${ }^{17}$ Ahmet Çiğdem, Bir Imkân Olarak Modernite: Weber ve Habermas, İstanbul, 1997, s. 57.
}

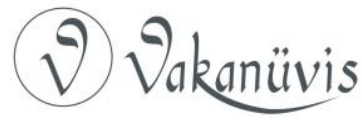


yönü daha sonra dünya çapında gerçek bir girişim ve inisiyatif pratiğine dönüşecektir.

18. yüzyılın entelektüel yaşantısı önceki herhangi çağdan daha karışıktı. Almanya'nın Kant'la başlayan entelektüel üstünlüğü Alman tarihini büyük ölçüde etkilemiştir. Güçlü ulus anlayışı entelektüel öğretilerle desteklenmiştir. Örneğin, Johann Gottfried Herder, materyalist bir tarih düşüncesinin yetersiz olduğunun altını çizmiştir. Onun milliyetçilik, tarihselcilik ve milli ruh gibi kavramlarla alakalı düşünceleri yönlendirici bir unsur olarak yer almaktadır. Yeni "...klasisizm, rasyonalizm ve bilimsel metodun her şeye muktedir olduğu inancına" ${ }^{18}$ karşı romantik başkaldırısı ile seçilmiştir. Aydınlanma'nın karşıtı olarak Herder, rasyonalizme, bilimsel metoda ve anlaşılabilir kanunların evrensel otoritesine karşı tutumu bariz olsa da milliyetçiliğin ve edebi, dini ve politik irrasyonalizmin gelişmesi için çabalamıştır.

İdealizmi felsefe tarihinde materyalizmin karşısında bir kavrayış tarzı olarak kullana Alman düşünürleri Johann Gottlieb Fichte ve Friedrich Schelling Kant'ın getirdiği birleştirici ve idealist çözüm yolunu seçmişlerdir. Alman İdealist Felsefesinde, değişmez töz düşüncesini reddederek ve onun yerine evrensel yaşamı, bilinçsizlikten bilince doğru gelişen ve nihai amacı, insandaki kendi kendisinin bilincine varan akılı canlı, yaratıcı ve amaçlı bir evrim ilkesi göre yorumlamaktadırlar. Schelling, Fichte'den aldığı "zihinsel görü" (intellektuale Anschauung) ve Spinoza'dan aldığı "yaratıcı doğa" (natura naturans) kavramlarıyla doğayı kendi kendini durmaksızın açan, yaratan, üreten organik bir bütün varlık olarak kavramaktadır. Alman idealistlerinde gördüğümüz felsefeyi bir bilim seviyesine yükseltme çabası idealizmin temel sorunlarından birisidir. Doğayı bir sanat eseri olarak gören Schelling, Fichte'nin diyalektik düşüncesini doğaya uygulamaktadır.

Georg Wilhelm Friedrich Hegel "Tarih Felsefesi" adlı kitabında, Avrupamerkezci çizgideki ilerleme ve uygarlık kavramını diyalektik safhalara bölünerek şerh etmiştir. Dünya tarihinin farklı evrelerinin

18 Herder, J. G. Another Philosophy of History and Selected Political Writings (I. D. Evrigenis ve D. Pellerin, Çev.). Indianapolis: Hackett, 2004, s. 118-122

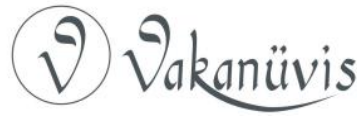


uygarlık yenilenmeleri ile izahı soyut ve akademik olmanın ötesinde nesnel anlam taşımaktadır. Bu çalışmalar ahlaki ve kültürel hegemonyanın ayrımlarını anlatmak konusunda yeni metodolojik yaklaşımları ortaya çıkarmaktadır. Örneğin, Doğu uygarlığının ilerleme tarihi sürecinde çocukluk evresi olarak verilmesi. İslam dünyasını ise daha doğrusu Hegel'in ifadesiyle "Muhammedcilik" toplumunun alt bölümde konumlandırılması. Dünya tarihinin ilerleme istikametinde kurgulanan formasyonların "ilk Despotizm, ikincisi Demokrasi, üçüncüsü ise Monarşi” ${ }^{19}$ biçiminde sıralanması Batı hegemonyasıyla yakından bağlıdır. Yani kültürel-siyasal idare anlamında Doğu despotizmin temsilcisi olarak belirtilmektedir. Söz konusu formasyonlarda evrensel istikâmet ve onun gelişim yolu dört uygarlık safhasında ortaya çıkartııı: "Doğu, Grek, Roma ve Germen uygarlığının biçimlendiği evre." ${ }^{20}$ Burada Hegel tüm uygarlıkların gelişiminde Germen ulusuna en yüksek rolü atfetmektedir. Hegel'in Alman yurtseverliğinin Prusya hayranlığıyla özdeş tutulması Alman tarihçileri (Mommsen, Treitschke) tarafından daha ileri noktalara taşınmıştır. Bununla birlikte, Alman ırkının Prusya egemenliği altında toplanması süreci diyalektik bir tecessüm olarak görülmüştür. ${ }^{21}$ Dünya tarihinde uygarlığa dayalı sistemlerin inşası Hegel'e göre "ulusal deha"nın ${ }^{22}$ katkılarıyla sağlanmaktadır. Ayrıntıya girmeden, "ulus" (volkgeist) kavramı Hegel'de tarihin itici gücü demektir. Karl Marx için sınıf mücadelesinin tarihi gelişmelerde oynadığı rolü Hegel'in konseptinde uluslar oynamaktadır.

Hegel ve Marx'ın "ilerlemeci tarihi evrim" çizgisi arasındaki benzerlik dizisi evreler şeklinde birbirinden ayrılmaktadır. Batı'nın ilerlemeci problemine ilişkin Marx'ın tarihsel materyalizm diyalektiği "Alman İdeolojisi" adlı kitabında feodalizm, kapitalizm ve sosyalizm formasyonu şeklinde aktarmaktadır. ${ }^{23}$ Hegelci yaklaşımla

${ }^{19}$ Georg Wilhelm Friedrich Hegel, Tarih Felsefesi, çev. Aziz Yardımlı, İstanbul, 2006, s. 83.

${ }^{20}$ Bertrand Russell, Batı Felsefesi Tarihi: Modern Çağ-Yeni Çağ, çev. Muammer Sencer, Ankara, 1972, s. 372.

${ }^{21}$ Joseph A. Buttigieg (ed.), Antonio Gramsci: Hapishane Defterleri, C. 4, çev. Ekrem Ekici, İstanbul, 2011, s. 220

22 Russel, Batı Felsefesi Tarihi: Modern Çağ-Yeni Çă̆, s. 376.

${ }^{23}$ Karl Marx - Friedrich Engels, Alman Ideolojisi, çev. Olcay Geridönmez - Tonguç Ok,

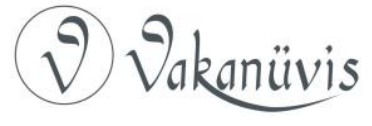


ilerlemeci/doğrusal bir varsayımı "kendi içinde bir varlık" olarak görmüştür. Marx'in tarih düşüncesinde Hegel etkisi "ilerlemeci Batı ve durağan Doğu" denklemi ile çözümlenmeye çalışılmıştır. Özetle "Batı tarihsel gelişimin muzaffer taşıyıcısı, Doğu ise onun pasif alıcısı"24 konumunda ifade edilmektedir. Böyle bir süreçte Doğu ise "doğuş ve çöküş" 25 biçimini almaktadır. Marx'ın düşüncelerini temellendirdiği en önemli kavramlardan biri olan "yabancılaşma" kavramı tarihsel ilerleme teleolojisinin kaynağında Hegel'in "insanın kurtuluşu" sorununu evrimsel bir açılım biçiminde değerlendirmektedir. Marx, yabancılaşmanın başka bir görünümde yer alan fetişizmi kapitalist üretim tarzının hâkim olduğu düzende ortaya çıktığını söyler. ${ }^{26}$ Felsefe tarihi içerisinde "yabancılaşma" kavramını ilk kullanan isim Marx olmasa da "yabancılaşma" kavramının iktisadi bir olgu olarak ele alınıp, kapitalist üretim tarzı ile birlikte somutlaştırması derin tartışmalara yol açmıştır. Yakın dönemlerde Marshall G. S. Hodgson'un “Dünya Tarihini Yeniden Düşünmek", Edward Said'in "Oryantalizm" ve Samir Amin'in "Avrupamerkezcilik" adlı kitaplarında "yabancılaşma" kavramı, Batı'nın dışındaki toplumların tahakküme alınması kısmının tarih ve medeniyet ile olan ilişkisi üstü kapalı bir biçimde "öteki"ni vurgulamaktadır. Tarihi görünürde olduğundan daha derin gösteren bu yaklaşımda "Batı'nın eşsiz olduğu ve Doğu'da bulunmayan bir gelişimsel ilerleme kullandığı"'27 fikri dışlamacı tek taraflılık anlamında kullanılmaktadır.

Batı'nın her türlü teorik ve entelektüel oluşumunu 19. yüzyıldan beri rasyonellik ve modernite üzerinde temellendiren sosyolojik düşünce başlatıcıları kuramsal çerçeveyi kapitalist üretim biçimiyle genelleştirmişlerdir. Bunun yanında modernitenin en büyük savunucuları ekonomik bakımdan en ilerici sınıflar, tüccar çevreleri, toprak lordları, bankerler, toplumsal yaşamda idari konumda bulunan yöneticiler, eğitimli orta sınıf, imalatçılar ve girişimciler çıkara dayalı bir şevkle Aydınlanma ideolojisinin propagandasının yapıldığı Farmason

İstanbul, 2018, s. 28.

${ }^{24}$ Hobson, Batı Medeniyetinin Doğulu Kökenleri, s. 29.

25 Bryan S. Turner, Marks ve Oryantalizmin Sonu, çev. Çağatay Keskinok, Ankara, 1984,

s. 19.

${ }^{26}$ Ahmet Cevizci, Felsefe Sözlüğü, İstanbul, 2005, s. 1133.

27 Hobson, Batı Medeniyetinin Doğulu Kökenleri, s. 29.

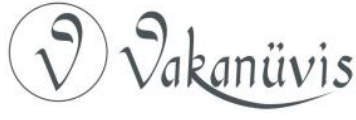


localardaki örtük faaliyetleri ile seçilirlerdir. ${ }^{28}$ Aydınlanma'nın 1789 Fransız Devrimi'ne etkisi toplumsal hayatın tüm geleneksel yapısını sarsan "güç-bilgi" görünümü bir olgu olarak sanayi ve ticaret burjuvazisinde açığa çıkmıştır. Kapitalizm formasyonun işlevselliğinde belirleyici olan yeniden üretim, ekonomik verimlilik ve kâr olgusu, merkez-çevre kutuplaşmasını ve sınıf mücadelesini bir sonuç olarak burjuvazi egemenliğinde biçimlenmiştir. Bu durumun hem Batı'da hem de Batı-dışında yarattığı insani tahribat yeni dağıtım ve tüketim rasyonalizasyonunu ortaya çıkarmıştır. Çünkü sistemin ekonomik ve askeri alanda yarattığı gerilimler daha sonra aşamalı şekilde kültürel ve zihinsel alanlarda tezahür etmiştir. En yaygın hata, tarihi kültürel etkileşim altında yatan farkları ve benzerlikleri açık şekilde kavrayamamaktır.

Aydınlanmanın "devrimci ideolojisi"29 Avrupa'da hâkim olan eski düzenin (anciens rejime) ortadan kaldırımasını stratejik bakış açısı belirleyerek aşmaya çalıştığı açıktır. İdeolojilerin belirleyici olduğu asıl Avrupamerkezci nokta burasıdır. Bu durumda Marx'ın Aydınlanmadan hareketle toplumsal dinamik sorununu Avrupa'ya özgü "akılla" özdeş sayması farklı yorumlara konu olmuştur. Marx'ın Doğu toplumları hakkındaki değerlendirmeleri bu bakımdan çok şaşırtıcı değildir. Marx'ın "Asya Tipi Üretim Tarzı" kavramı temelinde "ekonomik yapılar ve süreçler Doğu despotizmin politik nosyonuyla"30 ilgili müsvedde halinde bıraktığı metinlerde tarihsel özelliklerlerin tam olarak bilimsel izahını bulmadığı açıktır. Kendi kendine yeterlik üzerine bina edilen "durağan" Doğu yaşamında şehir, özel mülkiyet ve sınıf çatışması kavramının olmayışı iddiasının bilimsel içeriği tartışılabilir.

Batı'ya özgü rasyonellik ve analitik yöntemlerin Doğu'da olmadığı konusunda Israrlı olan Alman sosyolog Max Weber, politika ve ekonomik arasındaki ilişkiye dayanarak, Marx'ın toplum çözümlemelerinde ekonominin tayin edici rolünü eleştirmiştir. Bunu

\footnotetext{
${ }^{28}$ Eric Hobsbawm, Devrim Çağı: Avrupa 1789-1848, çev. Bahadır Sina Şener, Ankara, 2003, s. 29-30.

${ }^{29}$ Hobsbawm, Devrim Çağı: Avrupa 1789-1848, s. 31.

30 Bryan S. Turner, Oryantalizm, Postmodernizm ve Globalizm, çev. İbrahim Kapaklıkaya, İstanbul, 2003, s. 54.
}

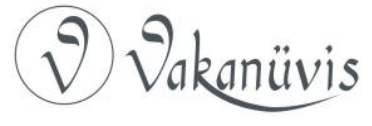


ortaya koyan örneklerden biri "şeref ve güç"31 yani "statü"32 kavramının toplumsal katmanlaşmada ekonomik koşullara indirgenmeyen özelliğidir. Batı hem liberal hem de büyümeye açık bir takım rasyonel yasayla kendini gerçekleştirdiği fikri kamusal ve özel mülkiyet ayrımı, özgür ve bağımsız şehirler, rasyonel yasalar, rasyonel bilim, Protestan ahlakı ve akılc bireyin doğuşu meseleleri etrafında Avrupamerkezci bütünü ortaya çıkarmaktadır. Doğu toplumları ise durağan özellikleriyle meselelerin pek çoğundan habersiz değişikliklerin sarsıntısını içinde düşmüş olduğu "geri kalmışlıktan" kurtulma arayışı içindedir. Doğu'daki yokluklarla karşılaştıran Batı'nın toplumsal güç dengesinde "politika ve iktidar (güç)"33 denklemi "irrasyonel ve rasyonel" yasalara göre belirlenmektedir. Bu denklemde yer alan Batı toplumlarının doğası ve Batılı yaşam biçimlerinin dünya üzerinde yayılma sebepleri Marx'ın varsayımlarının terstir. Doğu'yu gerileten etkenlerin başına din olgusunu koyan Avrupamerkezci görüşlerde, kadercilik ve konformizm tek yanlı bir perspektif olarak karşıya çıkmaktadır. Kapitalizm ekonomik işleyişlerin altını destekleyen temel unsurlar "bilim ve bürokrasi" ${ }^{34}$ olgusu, Weber, düşüncesinin önyargılarını yansıtan varyasyonlarından sadece biridir.

Tarihsel ilerlemenin (gelişimin) koruma ve yenileme diyalektiğinden türediği yöntem Benedetto Croce'nin estetik teorisinde edebi ve sanatsal klasisizmi oluşturur. Croce'nin tarihselliğinde "korumayenileme" üzerine çalışmaları nitelik bakımından "ulusal kültürü" bütün Avrupa kültürüyle canlandırılması meselesi durur. Yeni siyasi yapıların korunması ve savunulması çok kapsamlı bir boyutta hegemonya sorunlarını devletin bütünlüğü içinde ele alır. Croce için temel noktalardan biri Hegel'de olduğu gibi mantığı değil, tamamen bireysel ve duyusal olan sezgiselliği öne çıkarır. Ona göre tarih, Hegel'de olduğu gibi bir "mutlak tin"e doğru ilerleyen süreç olarak anlaşılmaz. Tarihte insanın kendi faaliyetlerinden kaynaklanan tinden başka bir tin yoktur. Yani "tinin kendisi bizzat tarihtir." ${ }^{\text {"35 }}$ Croce'nin "tarihsel-sezgisel" kavramı, tarih yazımının özünü ve sınırlarını bilme

\footnotetext{
${ }^{31}$ Turner, Marks ve Oryantalizmin Sonu, s. 73.

32 Bryan S. Turner, Statü, çev. Kemal İnal, Ankara, 2000, s. 65.

${ }^{33}$ Anthony Giddens, Sosyoloji, çev. Zeynep Mercan, İstanbul, 2012, s. 150.

${ }^{34}$ Giddens, , Sosyoloji, s. 151.

35 Özlem, Tarih Felsefesi, s. 150.
} 
zorunluluğu olarak kabul edilir. Bu demek oluyor ki, bütün bilgi etkinliğinin kavramsal temelinde uygulanan bütün ilişki biçimlerini "tarihsel-sezgisel kavrayış" hüviyetiyle irdelemektedir. "Tarihselsezgisel bilme" kavramı bu bilgi etkinliğini bünyesinde barındırmaktadır. Croce'ye göre "mantık düşünce bilimidir, tarih ve sanatın sınırlarını tam anlamıyla çizen doğruluk ve yanlışlık arasındaki ayrımı ancak düşünce yapabilmektedir." ${ }^{\prime \prime 6}$ Croce, eleştirisinde dile getirilebilecek işe yarar konsept ise teorinin tarih ile tarihsel olgularla uyum içinde olması gerektiği şeklidir. Bu anlamda Groce, tarihi ilerleme düşüncesi çalışmalarına katkıda bulunmaktadır. Aslında Groce'nin genel görüşünde yer alan "hırs" kavramı, girişilen insani eylemden ziyade yapısal problemler açısından kurumlar ve sezgisel itibariyle karşııklı bağ|ılığı zorunlu kılan tayin edici niteliktir. Tarihsel hareketin itici gücünü teşkil ettiği dinamikler hem ahlaki hem de yapısal mahiyette tarihi ilerlemeye ilişkin etkiye sahiptir. Siyasi parti, ulusal ordu gibi oluşumların eylem dürtüsünü ortaya çıkaran inisiyatifler bu "hırsla" ${ }^{37}$ ilintilidir.

\section{Avrupamerkezci Meydan Okuma Karşısında Antitez Tartışmaları}

Batı'yı insanlığın geri kalanı üzerinde imtiyazlı konuma yerleştiren "entelektüel" ve "ahlaki" anlayış, Aydınlanma çağının itici gücüyle geçerliğini korumaktadır. Toplumsal, ekonomik ve teknolojik koşullara bağı olarak insanın sınırsızca yetkinleşebileceği fikri bu olgunun yapı taşını oluşturmaktadır. Daha sonra modernleşmenin biçimlendirici etkisini ön plana çıkaran 19. yüzyıl tarihi yeni kavramsal şemaları Batı'yı yücelten bilinçlilikle genişlenmektedir. Modernleşmenin doğuşunda hegemonya katkısının belirgin biçimde göze çarpması tespit bakımından önemlidir. Öne çıkan eleştirel görüşlerde Aydınlanma rasyonalitesinin arkasındaki gizli tahakküm ve baskı mantığının saklanmış olması sorunu zaman-mekân düzleminde çözümlemek bugün de önemini korumaktadır. Aydınlanma eski eşitsizliğin adaletsizliğini toprak beyliğinin dolaysız tahakkümünü sona erdirse de kendi tahakkümünü evrensel dolayım aracılığıyla ebedileştirmek iddiasını gütmesi üstesinden gelinecek kolay sorun

\footnotetext{
${ }^{36}$ Goolingwood, Tarih Tasarımı, s. 190.

${ }^{37}$ Buttigieg (ed.), Antonio Gramsci: Hapishane Defterleri, C. 4, s. 174.
}

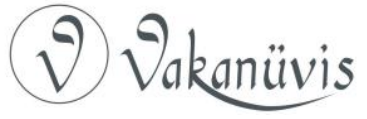


değildir. ${ }^{38}$ Avrupamerkezci anlayışın meydana getirdiği algının bilimsel ve akademik dille çözümlenmesi çağdaş felsefi ve tarihi yaklaşımlar istikâmetinde yeni tartışmaların temelini oluşturmaktadır.

Geleneksel toplumdaki egemen otoriteler, hukuksal, kültürel, ritüel ve gündelik hayata dayattığı tek tipli düzenlemeler ve denetim olgusu sistemin asıl sağlıklı olmayan biçimini ifade etmektedir. Otoritenin meşruluğunu temin etmek ve kültürel süreklilik için zorunlu olarak belirlenen bu hatlar önemli bir kıstas olarak eleştirilerin odağında yer almaktadır. Fakat temel çelişki modern toplumların hayatında da iş bölümü, mekanik dayanışma, iş saatleri endüstriyel teknolojinin egemenliği ile ilişkilendirdiğimizde denetim ve düzen tahakkümü üzerine temellendirilen bir paralelliği içermektedir. Toplumsal değişimin umut ve sorunlarına yönelik modernleşmenin ortaya koyduğu varyasyonlarda bir dizi etkiler yeni sitemin karakteristiği olarak gözetim ve denetim mekanizmalarını formaca farklı tesisi etmektedir.

Kültürel, hukuksal, politik ve ekonomik ayrıcalıkları içinde yer alan 19. yüzyılın rekabetçi koşulları özlü bir biçimde formüle etmektedir. Bir bakıma yargıların ve eleştirilerin odağını toplum biçimi kavramı kapsamaktadır. Hegemonya psikolojinin temelindeki düşünce "modernitenin geçmişi olduğu gibi geleceği de tekeli altına aldığı"39 iddiasıyla hareket etmektedir. Bu yaklaşıma dair ilk eleştirel duruş, bilhassa Friedrich Nietzsche felsefesinde açık ifade edilmektedir. Nietzscheci perspektiften Hristiyanlığın kölelik ahlakı kahramanlık erdemlerinin zıddı olarak görülmekte, kişisel yaratıcılığı yok eden ahlaki sistem içinde kategorize edilmektedir. Hristiyan ve İslam dininin erdemleri hakkında Nietzsche'nin 1888 yılında yayınlanan "Deccal” adlı kitabındaki yorumu Avrupamerkezcilik için ciddi eleştiriler doğurmaktadır. Bu açıdan Nietzsche, "Hristiyanlığı, nasibi kıtlara, zayıflara duyulan acımadan doğan eylem" ${ }^{40}$ diye yazmaktadır. Bununla birlikte Nietzsche "Şen Bilim" adlı kitabında "kontrollü dünya" fikrinin

\footnotetext{
38 Theodor W. Adorno. - Max Horkheimer, Aydınlanmanın Diyalektiği, çev. Nihat Ülner - Elif Öztarhan

Karadoğan, İstanbul, 2014, s. 30.

${ }^{39}$ Çiğdem, Bir Imkân Olarak Modernite: Weber ve Habermas, s. 67.

${ }^{40}$ Friedrich Nietzsche, Deccal, çev. Oruç Aruoba, İstanbul, 2000, s. 2-3.
}

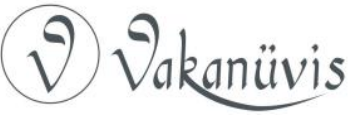


Aydınlanma "semptomundan" kaynaklandığını açık dile getirmektedir. Aydınlanmanın "manevi sömürü" (kör inanç) formülünün bir "ahlak çöküntüsü" ${ }^{41}$ olduğu ve modern kurumların kültürel temelini teşkil ettiği fikrini özenle savunmaktadır. Deneyime dayanan Aydınlanma eleştirmenleri, Nietzsche'ye gerçekten yakın olan görüşlerini "hegemonya" noktasında bu bağlam içine yerleştirmektedirler. Sahip oldukları farklı tarihsel ilerleme çizgisi anlayışında entelektüellerin ahlak vurgusu tarihsel-kültürel sorunlarla kategorize edilmektedir. "Nietzscheci" görüş savunucularının ortak özelliği meselelere karşı epistemolojik tavır alışlarıdır. Entelektüellerin yeni durum sayesinde ortaya çıması yeni bir ideolojinin tipik göstergesidir. Çünkü aklın ve gerçekliğin hakikat olmadığını öğreten Nietzsche'dir. İnsan yaşamı kavramını "bilgi ve güç" birliği anlamında izah eden Nietzsche, tarih düşüncesini Foucault'nun çözümlemelerinden farklı olarak "öfke" kaynağına dönüştürmektedir. Foucault'ya göre ise:

"Her bilgi ve hatta bilim iktidar arzusunun bir aracıdır. (...) Bilgi dallarının hepsi egemen olma stratejilerine uyar; aslında bu dallar insanın ve yeryüzünün daha iyi denetlenmesini sağlayacak biçimde kendi nesnelerini türetirler. Akıl bir iktidar teknolojisi, bilim ve egemenlik aracıdır. ${ }^{\prime 42}$

Burada söz konusu olan yönelim Aydınlanma ile egemenlik arasındaki ikircikli ilişkidir. Çünkü Nietzsche, Aydınlanma'yı “...hem egemen aklın evrensel hareketi hem de yaşama düşman 'nihilist' bir erk"43 olarak görmektedir. Batı'nın "ilerleme" kavramının eleştirisine ilişkin kendinden emin şekilde alternatif bir tanımlama getirerek şöyle yazmaktadır:

"ilerleme, modern bir düşüncedir yalnızca, yani, yanlış bir düşünce.

Bugünün Avrupalısı, değerlilik bakımından, Rönesans Avrupalısının fersah fersah altında kalır; ileriye doğru gelişme, herhangi bir zorunlukla yükselme, yücelme, güçlenme değildir." ${ }^{\prime 4}$

Aydınlanma ile tahakküm arasındaki ilintide kavramsal ve felsefi ayrımlar Avrupmerkezci hegemonyanın değişen karakterinde

\footnotetext{
${ }^{41}$ Friedrich Nietzsche, Şen Bilim, çev. Ahmet İnam, İstanbul, 2011, s. 44.

42 Merquior, Foucault, s. 194.

${ }^{43}$ Adorno - Horkheimer, Aydınlanmanın Diyalektiği, s. 69.

${ }^{44}$ Nietzsche, Deccal, s. 2.
}

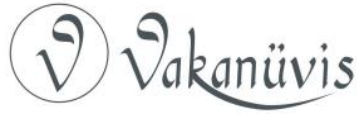


belirginleşmektedir. Batı tipi modernleşmede de anti-sömürgecilik olgusu bir dizi çekirdek konuyu kilit terimlerin etimolojisinde açığa çıkarmaktadır. "Avrupamerkezcilik" kavramına dair ne kastettiğimizin temel örneklerinden biri Gramsci'nin dile getirdiği "egemenliğin uygulandığı zeminde 'baskı ve rıza'nın bütünleyici ilişkilerinin hegemonya alanında tespit edilebilmesi sorunudur." 45 Hegemonya fikri, hegemonya uygulanacak kesim ve alanların çıkar ve eğilimlerini dikkate alma noktasında belirli bir uzlaşma dengesi kullanılmaktadır. Çünkü toplumsal değişim sürecine ilişkin egemenlik ve entelektüelahlaki yönlendirme daha çok sorunların çözümüne bağlıdır. ${ }^{46}$ Tüm bunları yüzeye çıkaracak sorunlar Gramsci'nin "hegemonya" kavramıyla doğrudan doğruya bağlantılıdır.

Sınırları bir sömürge yönetimince belirlenmiş olduğu koşullarda toplumsal oluşumun birliğine simgesel anlamlar yüklemek için nihai çözümlemede Avrupamerkezci temanın başat bir rol üstlendiği söylenebilir. Gramsci'ye göre Batı'daki toplumsal değişimlerde belirleyici olan çatışma ve krizin etkileri şu şekilde farklılaşmalarla sıralanmaktadır:

"Tarihsel süreçte temel bir Batı birliği var olmuştur, Ortaçağ Hristiyan-Katolik; temel bir bölünme ya da kriz, Reformasyon ve din savaşları. Reformasyon'un ardından, din savaşlarından nerdeyse iki yüzyıl sonra Batı'da ikinci birliğe, tüm Avrupa'da yaşamın içine nüfuz eden ve on sekizinci ve on dokuzuncu yüzyılda doruk noktasına ulaşan, farklı türde ikinci bir birliğe ulaşılmıştır. Bu birlik üç sütun üzerine oturur: eleştiri ruhu, bilimsel ruh, kapitalist ruhu."

Gramsci, "Hapishane Defterleri" adlı kitabında Avrupamerkezci temaları ortaya çıkaran konjonktürü hegemonik kavramlar çerçevesinde çözümlenmektedir. Özellikle, temel egemenlik kavramlarını kapsayan hegemonya, rıza-baskı, sivil toplum, iktidar, Doğu-Batı gibi tanımlamaları Avrupamerkezci düşüncenin tesir metotlarını teşkil etmektedir. Gramsci'nin görüşüne göre düşünceler

\footnotetext{
${ }^{45}$ Stuart Hall ve dğr., Siyaset ve Ideoloji: Gramsci, çev. Sadun Emrealp, Ankara, 1985, s. 61.

46 Perry Anderson, Gramsci Hegemonya: Doğu/Batı Sorunu ve Strateji, çev. Tarık Günersel, İstanbul, 1985, s. 40.

47 Buttigieg (ed.), Antonio Gramsci: Hapishane Defterleri, C. 1, s. 221.
}

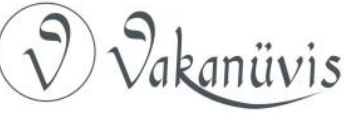


toplumsal ve tarihi içerikleri dışında işlev ve kökenlerinden ayrı anlaşılamazlar. Bu doğrultuda "...yeni bir türdeki tarihsel aşamanın başlangıcı 'politik - bilgi kurumsal' tez olarak epistemolojik sorun biçimde formüle edilmektedir. "48 Batı'nın toplum felsefesindeki başlıca kuramsal sorunlar siyasi-ideoloji temelde "devrimci fikirlerin ve eylemlerin" örgütlenme biçimine bağlanmaktadır. Buna ilave olarak Doğu'nun özellikle de İslam dünyasının rasyonel ve hesaplanabilir biçimde Batı'daki eğilimlerin kenarında kalmasını zihinsel bir durum değil, dinsel durum olarak belirlenmesi Gramsci tarafında şöyle açıklamaktadır:

"Aslında İslam'ın en trajik sorunu, yüzyllar boyunca izolasyon ve yozlaşmış feodal rejimler vasıtasıyla uyuşturulmuş olan bir toplumun, halihazırda çözülme aşamasına girmiş olan çılgın bir uygarlık ile aniden temasa geçirilmiş olmasıdır." ${ }^{\prime \prime 9}$

Batı toplumların tarihinde muhalefet (direniş) kültürünün oluşması toplumsal düzenlemelerde radikal ve topyekûn değişiklikleri kaçınılmaz kılmaktadır. Bu durum klasik Yunan ve Hristiyanlığın doğal süreç geleneğiyle tam bir tezat oluştursa da modernleşmenin kendi epistemolojik ve kuramsal alanı içinde muğlak sorunlardan biridir. Toplumsal hegemonyanın tesisinde ve yeniden üretilmesinde politik gücün rıza'ya dayanan işlevi eğitim görmüş kesimin tutumlarıyla belirlenmektedir. Batı siyasi yaşamının, teknolojisinin ve toplumunun modernleşmesinde en önemli husus entelektüellerin işlevini bu görüş içinde aydınlığa kavuşturmak mümkündür. ${ }^{50}$ Gramsci'nin açık biçimde gösterdiği gibi yeni bir tarihsel duruma geçişte "entelijansiya"nın yeni durum sayesinde ortaya çıkması hususi bir paradigma meselesidir. Yeni hayatın idamesi için entelektüeller güç arayışı mücadelesini ideolojik üstyapının temsilcisi olarak hegemonya kazanımlarında aramaları rasyonel bir iradenin oluşmasından kaynaklanmaktadır. En önemli işlevlerden biri geniş nüfus kitlesini belli bir kültürel ve ahlaki seviyeye yani yönetici sınıfın çıkarlarına ilişkin - ulaştırmada devlete önemli

\footnotetext{
48 Peter D. Thomas, Gramsci Çağı: Felsefe - Hegemonya - Marksizm, çev. Illker Akçay Ekrem Ekici, Ankara, 2010, s. 184.

${ }^{49}$ Buttigieg (ed.), Antonio Gramsci: Hapishane Defterleri, C. 1, s. 390.

${ }^{50}$ Antonio Gramsci, Hapishane Defterleri: Seçmeler, çev. Kenan Somer, İstanbul, 1986, s. 75.
}

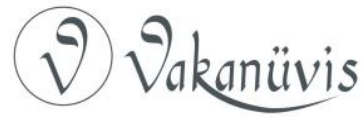


programlar sunmaya çalışmaktan ibarettir. Sayısız girişim ve mesleki faaliyetlerle (eğitim, okul, mahkeme, basın-yayın) "...yönetici sınıfın siyasal ve kültürel hegemonya aygıtı oluşturulmaktadır." ${ }^{\prime 51}$ Gramsci, umutsuzca, Tatiana Schucht'a yazdığı mektupta bu konudaki genel kanaatlerini şöyle izah etmektedir:

"Bu araştırma özsel sınırlarına kadar geri çekildiğinde dahi oldukça çetin ve geniş çaplı bir araştırmadır. Roma Imparatorluğu'na ve ürettiği ilk 'kozmopolit' (emperyal) aydın grubunun ortaya çıktığı döneme kadar geri gitmek gerekir. Daha sonra, emperyal aydın kozmopolitizminin mirasını bir Avrupa kastına dönüştüren HristiyanPapalık rahip örgütlenmesini vb. incelemek gerekir. 18. yüzyıl öncesinde, din-devlet arasındaki ilk yetki mücadelelerinin öncesinde, bir 'ulusal' ...aydın grubunun varlığından söz etmenin olanaksızlığı yalnızca bu şekilde açıklanabilir."

Hegemonya konseptinin tam olarak ne anlam ifade ettiğini anlamak için "nesnel olarak gerçek" olma niteliğini kaybetmeyen "Doğu" ve "Batı" konseptleri örneğinde entelektüellerin mesleki faaliyetlerine bakmak yeterlidir. Tarihsel modernizasyon sürecinde iktidarın işlevselliğini meşrulaştıran "bürokratikleşme" olgusunun toplumsal bütünlüğün bütün hayat alanlarına açtığı çıkışla belirlenebilmektedir. Devletin genel nosyonu altındaki esas unsurlar bu çerçeveye dâhil edilebilir ki "devlet = siyasal toplum + sivil toplum anlamında, denetim zırhıla korunan hegemonya, düzenlenmiş toplumun unsurlarının gelişimini gözetecek bir baskı organizasyonu olarak" ${ }^{\prime 23}$ geçiş evresini gerçekleştirmeye çalışmaktadır. Modern bilincin yaygınlaşması ve hayat tarzlarının rasyonelleşmesi evrensel-tarihsel perspektif içinde yeniden kurumsallaştırılması kolektif bir varlığın ürünü değildir. Sınıf veya tabaka kavramının dışında eğitilmiş grup ve bireyin "akıl tasarısı" (hegemonya) tarafından onaylayacağı toplumsal ve siyasal işlevleri bilim, sanat ve kültür değerlerini üretimine yöneliktir. Bir tarafta toplumsal sorunların pratik-teknik çözümlerine katkıda bulunmaları, diğer tarafta geleneğin ahlaki-estetik içeriğini boşaltarak rasyonel prosedüre itaati tesis etmeleri hegemonyanın dolaysız bir sonucudur. Gramsci'nin altını çizdiği gibi "hegemonya evresi ve devlet iktidarı

\footnotetext{
51 Buttigieg (ed.), Antonio Gramsci: Hapishane Defterleri, C. 4, s. 202.

52 Buttigieg (ed.), Antonio Gramsci: Hapishane Defterleri, C. 1, s. 57.

${ }^{53}$ Buttigieg (ed.), Antonio Gramsci: Hapishane Defterleri, C. 3, s. 218.
}

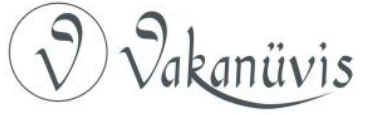


evresi rastgele uydurulmayacak belirgin entelektüel faaliyetleri içermektedir." ${ }^{154}$ Kısaca özetlersek, Batı'nın Avrupamerkezci söylemi, Doğu ile Batı arasındaki kesin çizgiyi entelektüel ayrımcı rejim yoluyla ayırmaktadır. Gözlemler göstermiştir ki, Batı emperyalizmin Doğu toplumları üzerindeki kültürel etkisi ekonomik etkisinden daha büyüktür.

Tarihi sürece yüklenen anlamı merkezi bir kavramın perspektifi dışında okumak, "rasyonalitenin tahakkümünden" 55 kurtuluş olarak değerlendirmek mümkündür. Bu konuya ilişkin Foucault'nun tarihi süreç hakkındaki şerhleri, ahlaki ve ideolojik oportünizme saplanmadan kavramsallaştırmış ve dogmatik ya da deneysel yollarla çözüme kavuşturulmamış problemlerden bir arşiv inşa etmiştir. Tarihsel metodolojiye yeni bir felsefi bakış getirerek, değişiklikleri "bilgi ve güç" arasındaki örtülü geçişlerle çözümlemiştir. Bunlar birçok düşünceyi tetikleyen ana bileşendir. Yeni perspektiften bakıldığında, toplum üzerine hegemonik bir kültür modelinin inşası bütünleşme ilişkileri üzerinedir. Yani toplumsal ve siyasal formların pratiğine yeni bir bakış açısı kazandırmakla evrensel hale gelen öznenin nesnelleşmesi sürecidir. "iktidar ve bilgi" ilişkileri Foucault'nun yapıtları üzerinde manyetik etki yaratmaktadır. Keskin fikir tarafından çizilen problematik şemada gerçekliği iktidarın boyunduruğundan kurtarma sorunu değil, gerçeklik iktidarının içinde hareket ettirilen toplumsal, ekonomik ve kültürel hegemonya biçimlerindeki ayrımlardır. Burada geçen Gramsci'nin "hegemonya" kavramının bu diyalektikle uygunluk teşkil etmesi ilgi çekicidir. Çünkü Gramsci'nin "hegemonya" teorisinin özü "sırf sınıf iktidarı yoluyla kültürün belirlemesi değil, toplumsal denetim uğruna yönetici sınıf kültürünü kendine mal etmesidir. "156

Foucault insanlığın ilerlemesinin ya da ilerlememesinin kanıtlarını eski siyasal rejimlerin yıkıntılarında, en köklü devletleri dahi ortadan kaldıran büyük felaketlerde, kökü sağlam olmayan devletleri yıkıp onların yerine yenilerini biçimlendirmesiyle bağlantılıdır. ${ }^{57}$

\footnotetext{
${ }^{54}$ Buttigieg (ed.), Antonio Gramsci: Hapishane Defterleri, C. 2, s. 216.

55 Çiğdem, Bir Imkân Olarak Modernite: Weber ve Habermas, s. 196.

${ }^{56}$ Merquior, Foucault, s. 195.

57 Michel Foucault, Özne ve İktidar, çev. Işık Ergüden-Osman Akınhay, İstanbul, 2014, s. 168.
}

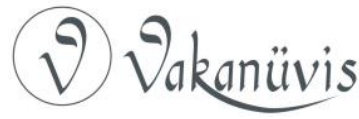


Foucault'nun mantık çözümlemesine göre:

"Aydınlanma, hem Avrupa modernliği başlatan apayrı nitelikteki bir olay olarak hem de aklın tarihinde, rasyonalite ve teknoloji biçimlerinin, bilginin özerkliği ve otoritesinin gelişmesi ve yerleşmesinde kendini göstermiş kalıcı bir süreç olarak, bizim için salt düşünce tarihinin bir epizodundan ibaret değildir. Aydınlanma, 18. yüzyıldan beri düşüncelerimize nüfuz etmiş bir felsefi sorundur. ... Hem tarihte bir olay, bir kopuş, bir altüst oluş olarak, bir başarııızlık hem de bir değer olarak, tarihte ve insanlığın ilerlemesinde etkili olan devrimdir. ${ }^{\prime \prime 58}$

Foucault'nun siyasi modernliğin eşiği olarak adlandırdığı 18. yüzyııın sonu ile 19. yüzyılın başına tekabül eden bu dönem, aynı zamanda kapitalizmin ihtiyaç duyduğu emek gücünün kaynağı olan insan bedeninin doğrudan doğruya ekonomik ve siyasi müdahalelerin nesnesi haline geldiği dönemdir. ${ }^{59}$ Avrupa'da ortaya çıkan, Foucault'nun "disiplinci iktidar" ${ }^{60}$ adını verdiği yepyeni bir iktidar türü yeni istatiksel kaydetme, işaretleme, betimleme, sınıflandırma ve yeni öğretim gibi bilginin koşulları bu görüngünün belirleyici özellikleridir. Gelgelelim bu kategoriler bütünün gidişatı açısından bilgi akışını sağlama, başka teorik alanlara nüfuz etme ve başka kurumlarla ilişki biçimlerini tesis etme ile yeniden tanımlamaktadır. ${ }^{61}$

"Panopticon"* kavramı, bireyleri kullanma biçimlerine bakıldığında uyum sağlama aygıtı rolünü üstlenmektedir. Modern dünyanın felsefi ve hukuki inşası kararlı biçimde "toplumları disiplin altına alan"62 bakış açısından türetilmektedir. Foucault, "Panopticon" kavramını "bir

\footnotetext{
58 Foucault, Özne ve iktidar, s. 171.

59 Michel Foucault, Büyük Kapatılma, çev. Işık Ergüden-Ferda Keskin, İstanbul, 2011, s. 14.

60 Foucault, Büyük Kapatılma, s. 218.

61 Michel Foucault, Bilginin Arkeolojisi, çev. Veli Urhan, İstanbul, 2016, s. 73.

* Panopticon tasarımı - "Denetim evi" anlamına gelen tasarım, J. Bentham tarafından 1785 yılında tasarlanan bir hapishane modelidir. Tasarımın temelinde yatan ilke gözetleme ve kontrol üzerine inşa edilmektedir. Şöyle ki; bütünü (pan-) gözlemlemek (opticon) anlamına gelen bu tasarım birkaç katlık tek odalı hücrelerden oluşan bir halka üzerine kurulmaktadır. Dış cephedeki duvarın penceresinden gelen dış ışığın kuledeki nöbetçilere mahpusun her hareketinin iyi aydınlatılmış bir silüetini izleme olanağını sağlamaktadır.

62 Foucault, Büyük Kapatılma, s. 18.
}

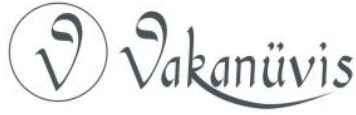


toplum ve bir iktidar türünün ütopyası"63 olarak Aydınlanma içeriklerinin bir parçası şeklinde görmektedir. Foucault'ya göre 19. yüzyılın başında hiç kuşkusuz sanayi toplumunun işleyiş koşullarını belirleyen ve kapitalist ekonomisinin altyapısına hizmet eden siyasi iktidar biçimi Jeremy Bentham'ın "Panopticon" modeline uygun tertip edilmektedir. ${ }^{64}$

Batı'ya özgü belirginleşen modern ideoloji Rönesans'tan Aydınlanma sürecine uzanan üç yüzyıllık zaman kesiminde Avrupamerkezli iddialar egemen kültür boyutunu 19. yüzyılda "Ezeli Batı"65 kurmacasıyla bir araya getirilecektir. Bir güç olarak kendini gösteren önyargıların insanı özneye dönüştürdüğü sorununu üç ayrı nesneleştirme kipinde öne çıktı̆ı̆ı ı Foucault şöyle sıralamaktadır: "Kendilerine bilim statüsü veren konuşan özne, emek üreten özne ve biyolojik anlamda yaşayan özne."66 Böylece insanlar öznesi haline geldikleri deneyimlerin çerçevesinde bilimsel, ahlaki, hukuki, siyasi normlara göre hareket etmekte ve kendilerini sınırlamaktadır. 19. yüzyıldan itibaren ise dünya tarihini bu üç modelden hareketle yeniden yazıldığı söylenebilir: "Ölçüt, kural ve sistem insanı mekâna kapatmak problematikasını"67 tarihi görüşle bütünleştirecektir. Bunun üzerine, egemen kültürcü bakışta Doğu, Batı́nın sömürgeci bilgisine sunulmuş, ama hep sınır olarak kaldığından erişilmez bırakılmıştır. Doğu, içinde Batı'nın oluştuğu, ama bir bölme çizgisi ile ayrıldığı ideolojik ihtiyaçları beslemektedir. Bu üç ana unsuru sırasıyla izlediğimizde “...Batı'nın bütün oluşumu boyunca büyük bölmenin tarihini yaptığını onu kendi sürekliliği ve alışverişleri içinde izlediğini, aynı zamanda kendi trajedi kutsallığı içinde ortaya çıktığını"68 görebiliriz. Çünkü yaşamın, emeğin ve dilin ampirik pozitiflikleri insanın varoluş tarzını karakterize eden tarihin bütünlük kavrayışını 19. yüzyılın başında seçkin tabaka ile halk kitlesi arasındaki ayrımdan, coğrafi mekâna (Doğu-Batı) kaydırmıştır. Mekânın parçalanmasıyla ortaya çıkan insan bir bakıma

\footnotetext{
63 Foucault, Büyük Kapatılma, s. 224.

${ }^{64}$ Foucault, Büyük Kapatılma, s. 126.

${ }^{65}$ Amin, Avrupamerkezcilik: Bir Ideolojinin Eleştirisi, s. 112.

${ }^{66}$ Foucault, Büyük Kapatılma, s. 15.

67 Michel Foucault, Kelimeler ve Şeyler, çev. Mehmet Ali Kılıçbay, İstanbul, 2001, s. 503.

68 Foucault, Büyük Kapatılma, s. 24.
}

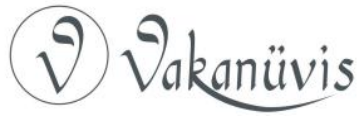


"tarihsizleştirilmiş"tir. ${ }^{69}$ Foucault'ya göre tarihin bütünlük kavrayışı Batı'nın episteme'sinin büyük altüst oluşu içinde kırılmış ve kendine özgü bir tarihsellik keşif etmiştir: Üretimin gelişim tarzları, sermayenin birikim tarzları ve fiyatların değişim yasaları ne doğal yasalarla birleştirmek, ne de insanın genel yol alışına indirgemek mümkündür. ${ }^{70}$ Fakat bu değişikliklerin tümü Batı'nın ilerleme düşüncesi içinde gerçekleşmektedir.

\section{Avrupamerkezcilikte Tarihselcilik* Kurgusu}

Dünya tarihinin bütünlük kavrayışının Batı ölçeğine göre kavramsallaştırılıp sunulması, temel kaynaklara istinat eden çok sayda tarihçi tarafından bilimsel olarak tartışmaya açılmaktadır. Batı merkezli dünya tarihinin yazımı sosyal bilimlerin nesnelliğine dair tarafsız bir izahat oluşturmadığı sebebiyle tarihi kayıtların dengesi ciddi bir şekilde tahrip olunmuş durumdadır. Tarih yazımının kronolojik kapsamı "Paleolitik çağdan postmodern döneme dek mümkün olabildiğince geniş tutulsa da Antik dönemi merkeze alan"71 Batı modernleşme sürecine ilişkin konular dördüncü yüzyıldan on dokuzuncu yüzyıla uzanan dönemde coğrafi kalıp içine alınarak işlenmektedir. Zaman ve mekân kavramına dayanan önceliklerin Avrupamerkezli tarih fikrinin ana karakterinde genellikle çarpıtılarak anlatılması tarihsellik probleminin açık bir belirtisidir.

Batı düşüncesinde Antikçağ'ın ortaya koyduğu felsefe-tarih karşıtlığında "geçmiş-şimdi-gelecek" üçlemesi döngüsel bir düzen içinde geçmekteydi. Helenizmin çöküşüyle Batı Hristiyanlığının doğuşu arasındaki "Avrupa'nın Karanlık Çağı"72 belirli bir öğretinin arkasından sona erdirildi. Yahudilik ve Hristiyanlık öğretisi, insani-toplumsal yaşama ilişkin olarak Antikçağ'ın tanımadığı yeni ve özel bir zaman anlayışı getirdi. Daha sonraki dönemlerde bu zaman anlayışı ne ölçüde laikleşmiş olursa olsun, Batı düşüncesinin ürettiği hemen tüm tarih

\footnotetext{
${ }^{69}$ Foucault, Kelimeler ve Şeyler, s. 513.

${ }^{70}$ Foucault, Kelimeler ve Şeyler, s. 512.

* Tarihselcilik - tarihin evrensel yasalara dayandırılarak belli bir ereğe, bir sona doğru aktığı görüşüdür. Tarihselcilik, totalitarizmi, determinizmi ve bir ölçüde fatalizm örtük olarak içeren evrenselci/teleolojist tarih görüşlerin müşterek adıdır (Özlem 1999: 67).

71 Jack Goody, Tarih Hırsızlığı, çev. Gül Çağalı Güven, İstanbul, 2012, s. 11.

72 Robin Gollingwood, Tarih Tasarımı, çev. Kurtuluş Dinçer, İstanbul, 1990, s. 166.
}

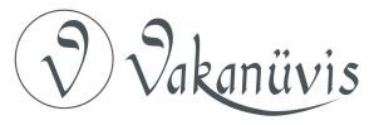


felsefede belirleyiciliğini korudu. Görüldüğü gibi yukarıda sözünü ettiğimiz tarih anlayışını temellendiren kişi, Aurelius Augustinus (354430) idi. Onun Hristiyan teolojisi ışığında geliştirdiği tarih anlayışı tüm Ortaçağ boyunca Hristiyan Kilisesi'nin resmi anlayışı oldu. Augustinus'la birlikte, "döngüsel" tarih anlayışının yerine "çizgisel" tarih anlayışı getirildi. ${ }^{73}$ Tarihsel düşüncenin epistemolojik statüsü ve kültürel işlevi zaman ve mekân açısından değerlendirildiğinde yaslandığı ideolojik konum Batı'ya özgü söylem biçiminde kurgulandı. Sunulan bakış açısı tam şekilde kavramlara dökülmemişti. Bu çizgisel tarih anlayışı bütüncül bir yaşam felsefesini ihtiva etmekteydi. Tarihi sürecin bir hedefe doğru ilerlediğini varsayan teleolojik görüş "teodise"*74 haline getirildi.

Bütün tarihsel olay ve olgular için tek kronoloji çerçevenin benimsenmesi Ortaçağ döneminde belirginleşti. Ortaçağın kapanışıyla Antikçağ’a duyulan yeni ilgiye karşın Rönesans insan anlayışını kendi felsefesinin merkezine aldı. Yeni akımın temsilcileri çoğu italyan kökenli kimseler kendi kökleri hakkındaki bilgisizliklerini gizleyen efsaneleri yıkmaya girişerek, Ortaçağ hatalarından kendilerini kurtardılar. Rönesans temsilcileri Yunan-Roma tarih anlayışındaki birçok öğeyi yeniden canlandırırken, tarihin değerinin siyaset sanatında ve insanları eğitebilen değer olduğu tasarımında yeniden canlandırdılar. ${ }^{75}$ Rönesans'ın Batı tarihinin küresel bağlamda kendine mahsus açılım şeklinde bir anlayış ifade etmesi zaman ve mekân örneğinde kurgulanmaktadır. Tartışmanın çerçevesini oluşturan "zamanın tekelleşmesi"76 kavramı Batı'ya aittir. Tarihin dayandığı takvim İsa'nın doğumundan (Milat) önce ve sonra olarak kullanılmaktadır. Antikçağ'da ölçüm, güneş, cıva ve su saati biçiminde var olmuştur. Daha sonraki dönemlerde zamanın bölümlenmesi genel yönüyle Güneş döngüsüne göre ayarlanmıştır. Hristiyan takvimine göre çizgisel tarzda yapılan hesaplanmalar kesintisiz biçimde doğumdan ölüme doğru hareket eden yaşamın ayrılmaz parçasıdır. Pazar gününün tatil günü olduğu yedi günlük haftanın yanı sıra Noel, Paskalya, Cadılar

\footnotetext{
73 Doğan Özlem, Tarih Felsefesi, İstanbul, 2012, s. 23.

* Teodise - Tanrı savunusu veya kanıtlaması.

${ }^{74}$ Edward Hallett Carr, Tarih Nedir?, çev. Misket Gizem Gürtürk, İstanbul, 2002, s. 125.

75 Gollingwood, Tarih Tasarımı, s. 76.

${ }^{76}$ Goody, Tarih Hırsızlığı, s. 17.
}

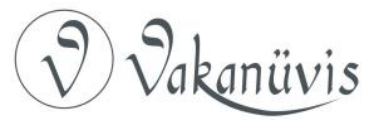


Bayramı gibi yıllık bayramların referans noktası Hristiyanlıkla ilgilidir. Tarih yazımında dinin süregele etkinliği Avrupamerkezci tarihin dönemlere ayrılmasında ve çağların şekillenmesinde etkili olan temel özelliktir. J. Goody'nin ortaya koyduğu tanımda Batılı zaman algısının çizgisel, Doğu'nun ise döngüsel niteliğini şu şekilde karşılaştırılmıştır:

"Kültürlerini ve potansiyellerini mutlak, kategorik, hatta özcü tarzda hatalı bir şekilde karşılaştıran bu genelleştirme tarihi gerçeği değiştirmez. Çin'de dönemlerin süreli hesaplanmalarından farklı, aynı ismin düzenli olarak tekrarlanacağı biçimde yılların kısa süreli döngüsel bir hesaplama olduğu gerçektir. Batı takviminde ise kendilerini tekrarlayan aylar ve bu ayların Çin yıllarına benzer karakterolojik eğilimi vardır. ...Döngüsel yerine çizgisel tarzda yapılan zaman hesaplamasına yönelik her düşünce, ileri, geleceğe dönük Batı ile durağan geriye bakan Doğu'ya dair hatalı algımızı yansıtan bir düşüncedir."177

"Annales" tarihçileri, tarihin tek boyutlu bir zaman olarak kurgusunu zamanın göreceli ve çok katmanlı olduğunun altını çizerek bu kavrayışı kökünden değiştirdiler ve yepyeni bir tarihsel kavram başlattılar. Lucien Febvre'in "Il. Philippe ve Franche-Comte ile 16. Yüzyılda İnançsızlık Sorunu", Marc Bloch'un "Feodal Toplumu", Fernand Braudel'in "Akdeniz" adlı kitapları başta olmakla "Annales" tarihçilerinin araştırmaları çağlar boyunca değişim sürecinin çizgisel bir yöne doğru giden tarih fikrini büyük ölçüde terk ettiler. Tek bir tarihsel zaman yerine farklı uygarlık arasında değil, "her bir uygarlığın kendi içinde bir arada var olan çoğul zamanlar görüşünü paylaştılar."78 Çizgisel zaman kavramının terk edilmesiyle ilerlemeye olan güven ve onunla birlikte Batı kültürünün üstünlüğüne duyulan inançta yıkıldı.

Hayden White tarihyazımının kurgudan farklı olmayıp, onun biçimi olduğu görüşü “Metatarih: Ondokuzuncu Yüzyıl Avrupası'da Tarihsel İmgelem" adlı eserinde tarihsel anlatılarda hiçbir gerçek ölçütü olmadığını göstermeye çalışmıştır. Tarihsel bir anlatımın kurulmasına yönelik temel adımı belirleyecek olan bilimsel değil, estetik ya da ahlaki kaygılardır. Anlatıların biçimini ve belirli bir dereceye kadar içeriğini de

\footnotetext{
77 Goody, Tarih Hırsızlığı, s. 22.

78 Georg G. İgers, Bilimsel Nesnellikten Postmodernizme Yirminci Yüzyılda Tarih Yazımı, çev. Gül Çağalı

Güven, İstanbul, 2011, s. 57.
}

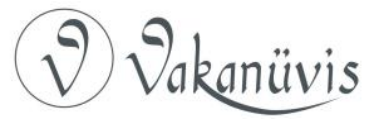


belirleyen sınırlı sayda retorik olanaklar vardır. Bu nedenle tarihsel anlatılar, içerikleri bulunmuş oldukları kadar icat edilmiş olan biçimleri bilimlerdeki benzerlerinden çok, edebiyattaki benzerleriyle ortak özellikler taşıyan sözel kurgulardır. White'a göre:

"Bu poetik edim, tarihsel alanı tikel türde bir bölge olarak yorumlanmaya hazır kılan dilsel edimden ayırt edilemez. Başka bir deyişle belli bir mekân yorumlanmadan önce ilkin belirli betilerin yer aldığı bir zemin olarak kavranmalıdır."

Batı'nın kendi ayrıcalığı üstüne geliştirdiği "zaman" kavramına paralel olarak "mekân" kavramı tarihsel kavrayışa dair yeni paradigma ortaya koymaktadır. Akademik varsayımları eleştirisiz bir şekilde kavrayan Batı merkezli dünya algısında dünyanın mekânsal bölünmesi hegemonyanın mantığı gereğidir. Öncelikle haritalar üzerinde kurgulanan Batı algısı tarihsel manevralarla gerçekleştirilmektedir. Çünkü haritalarda güdülerin yansıtılmasının yolları bulunmaktadır. "Mercator" projeksiyonuna dayalı üretilen dünya haritasında Batılı dünya algısı iddia edildiği gibi denizcilik için değil de karşılaştırılmalı şekilde kullanılacak alanlar açısından önem taşımaktadır. Dünya kıtalara bölünerek, Avrupa, Asya ve Afrika'nın boyutları tahrif edilmektedir. Mercator haritasında Kuzey'in kıta büyüklügü haritanın üçte ikisini Güney'in kara büyüklüğü ise üçte birlik bölümünü kapsamaktadır. Haritada Gröland Çin'den nerdeyse iki kat büyük görünüyor ki, aslında Çin Gröland'ın dört katı büyüklüğündedir. Hodgson bu projeksiyonu şu şekilde şerh etmektedir:

“Elbette mesele yalnızca Avrupa'yı büyük göstermek veya merkeze yerleştirmek değildir. Önemli olan harita projeksiyonu ile kavrayışlarımızın çok özel biçimde çarpıtılmış olmasıdır. Kırkıncı Kuzey enlemi dünya algımız için can alııı öneme sahiptir. Tarihsel bakımdan Avrupa hariç tüm büyük medeniyetler kırkıncı paralelin güneyinde yer almıştır." ${ }^{80}$

\footnotetext{
${ }^{79}$ Hayden White, Metatarih: Ondokuzuncu Yüzyıl Avrupası'da Tarihsel Imgelem, çev. Mehmet Küçük, Ankara,

2008, s. 47.

80 Marshall G.S. Hodgson, Dünya Tarihini Yeniden Düşünmek, çev. Ahemt Kanlıdere Ahmet Aydoğan,

İstanbul, 2017, s. 60.
}

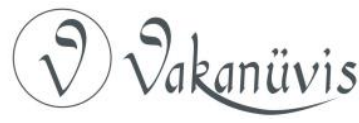


Avrupamerkezci hegemonyaya meşru kaynak olarak hizmete sunulan ırk özellikleri Batı'yı Doğu'dan ayırmak için kullanılan kategorik reaksiyonlardan biridir. Aydınlanma çağı öncesinde de var olan bu ayrım Aydınlanma'dan sonra rasyonelliğin gelişmesiyle "bilimsel girişim ve insan yaratıcılığının" 81 bir sonucu olarak öncekinden farklı bir duruma yönelmektedir. Antik Yunan'dan beri Rönesans düşüncesiyle temelleri atılan ve Aydınlanma ile şekillenen kategorik ayrımlar John M. Hobson'un "Batı Medeniyetinin Doğulu Kökenleri” adlı kitabında Avrupamerkezci bir okuma olarak kabul edilmektedir. Aydınlanma çă̆ında ortaya çıkan bilgilere istinaden Doğu'nun "Peter Pan" teorisi ile tanımlanması rasyonalite ile emperyalizm arasındaki karşılıklı bağlarla güçlendirilmektedir. Teoride Doğu duygusal bir kimliğe büründürülerek romantik çocuk imajıyla örtülmektedir. Batı'nın büyük bir fetih, nüfuz etme, kontrol ve mükâfat elde etme yolunda ilerlemesini, Ruyard Kipling'in "Beyaz Adam'ın Yükü" adlı şiirinde olduğu gibi Doğu'yu iyileştirme görevi "ahlaki" mesele şeklinde gösterilmektedir. Kipling'in ahlaki bakış açısı bir tarihsel gerçeklikle yakından ilişkili olduğundan emperyalist retoriği üzerinden yorumlanabilir. ${ }^{82}$ Edebi metinlere bağlanmış coğrafya, antropoloji ve biyoloji alanları 1840'lardan sonra "bilimsel" ırkçılığın doğuşunu bir dizi teori ve sınıflandırma ile geliştirilmiştir. Bilim alanlarının içeriğine nüfuz eden Charles Darwin'in "Türlerin Kökeni" adlı kitabının etkisi, Herbert Spencer'in çalışmasında "en uygun olanın hayatta kalması" 83 varsayımıyla sosyal boyuta geçmiştir. Batılı beyaz ırkın üstünlüğünü empoze eden bu görüşün yansımaları, ırksal ayrımcılık etrafında örgütlenen toplumların tarihsel olarak sömürgecilik eğilime sahip olduğu şeklinde görülebilir.

Dünya tarihinde ilk kez toplumların gelişiminin genetik özelliklere bağlanması, Avrupamerkezci eğilimin özel kısmını oluşturmaktadır. Irkçı görüş ve politikalar tarafından benimsenmiş kriterlerde planlı değişmeyi içeren bir toplum modeli pozitivist yasalarla desteklenmektedir. Georges Cuvier'in "Regene animal" (Hayvanların Saltanatı), Comte de Gobineau'nun "Essai sur les inegalite des races"

\footnotetext{
81 Goody, Tarih Hırsızlığı, s. 28.

82 Buttigieg (ed.), Antonio Gramsci: Hapishane Defterleri, C. 2, s. 134.

83 Alan Swingewood, Sosyolojik Düşüncenin Kısa Tarihi, çev. Osman Akınhay, İstanbul, 1998, s. 74.
}

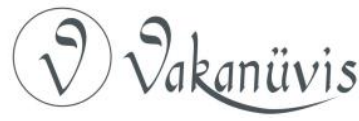


(Irkların Eşitsizliği Üzerine Deneme), Robert Knox'un "The dark races of man" (Insanoğlunun Karanlık Irkları) adlı kitaplarında sömürgeciliğe bilimsel gerekçeler üreten tezleri, insanları beyaz, sarı, siyah renge göre sınıflandırarak, toplumsal ırk ayrımına meşruluk örtüsü kazandırmaktadır. Hodgson’a göre "Modern Batı'daki ırk merkezciliğin en ilginç özelliklerinden biri, dünyanın diğer bütün ırk merkezciliklerini etkilemiş olmasıdır." ${ }^{84}$ Irkçı söylemin tarihsel düşünce yapısı içerisinde hegemonyaya hizmet etme kaygısı çağdan çağa çeşitlik göstermektedir. Böyle bir "bilim" anlayışı içerisinde oluşan tarihsel sürecin karakteristik özelliği Doğu-Batı çatışması diye adlandırabileceğimiz sömürgeciliğin dünya ölçeğinde yayılmasını keskinleştirmekten başka bir şey değildir.

"Tarihsel bütünlük" (historical complex) kavramını dünya tarihi sistemi üzerinde inşa eden Marshall Hodgson, "İslam'ın Serüveni" adlı yapıtında Batı merkezli terminolojiyi değiştirerek, dünya tarihi anlayışını değiş̧ik kültürlerin kesişmesi noktasında düzenlendiğini varsaymaktadır. Doğu'nun özelliklede İslam'ın önemini ortaya çıkararak, dünya tarihi hakkındaki algıları düzeltmeye yönelik araştırmalarında kavramsal ve metodolojik önermeler sunmaktadır. Burada dünya tarihinin "ana damarı"85 kavramı anahtar rolünü üstlenmekle birlikte, daraltılmış sınırları aynı derecede genişletmektedir. Kitapta göze çarpan önemli özellik İslam medeniyetinin dünya-tarihsel bağlamda düşünmenin tavizsiz ısrardır. Üç ciltten ibaret kitabın önde gelen konuları birbirinden farklı iki ana hat üzerinden değerlendirmek mümkündür: Birincisi, Kuran'ın mesajının, ideallerinin karşılık olarak içinde yaşadıkları çağın çıkmazlarını karşılamak üzere insanlara yol gösterme niteliğidir. Bu temelde İslam'ın tefekkür dünyasına ilişkin ahlak önderlerinin biyografisi yeni bir bakış açısıyla ele alınmaktadır. İkincisi ise Batı'nın "Büyük Dönüşümü" incelemesini şekillendirmeye katkıda bulunan "Tarım çağı ve Modern çağ arasındaki ikili ayrımdır."

Hodgson, dünya tarihinde modernlik görüşünü kültürler arası etkileşimden yola çıkarak, bütünleştirici eylem çizgisi gösterecek

\footnotetext{
${ }^{84}$ Hodgson, Dünya Tarihini Yeniden Düşünmek, s. 64.

85 Hodgson, a.g.e., s. 62.

${ }^{86}$ Hodgson, a.g.e., s. 530.
}

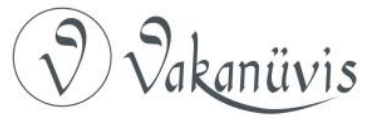


şekilde öngörmektedir. Batı tarihine indirgemeyen modernlik değerlendirmesini tarihsel zamanda Batı uygarlığının süreklikleri değil, kesintileri olduğu hususunda kanaati dikkat çekmektedir. Hatta tarihi düşüncede Avrupa'nın Asya kıtasının önemli bir parçası olduğunu, Rönesans'ın Avrupa'yı büyük medeniyetlerinin kültürel seviyesine taşıdığını iddia etmektedir. Hodgson'a göre:

"Modernlik ateşli silahların 16. yüzyılda ortaya çıkısıından başlayarak bütün şehirleşmiş toplumlar boyunca teknik uzmanlaşmanın artan ölçüde yayılmasının sonucudur." ${ }^{\prime 87}$

Batı bölgesindeki kültürel dönüşüm alanlarının iki hadiseyle zirveye ulaştığının altını özellikle çizmektedir: Uzmanlaşmış teknik gelişmeye bağlı olan Sanayi Devrimi ve Fransız Devrimi. Söz konusu hadiselerin doğurduğu eğilimin Doğu ve Müslüman toplumları üzerinde yarattığı yıpratıcı etki Sanayi Devrimi ve Fransız Devrimi'nden sonra üçüncü kuşağın faaliyetinin ana yöntemleriyle sağlandığı açıktır. 1800'lerde Avrupa'nın dünyanın geri kalan bölgeleri üzerinde yarattığı tahakküm üçüncü kuşağın doğrudan doğruya hegemonyasının karakteristik özelliğidir. ${ }^{88}$ Bu çizgide olup bitenler hakkında Hodgson'un tespiti şu şekildedir:

"18. Yüzyıldan itibaren Garp'taki dönüşümün islam dünyasında göstermekte olabileceği bütün olumlu etkiler olumsuz etkilerce gölgede bırakıldı. Yüzyılın ikinci yarısında Osmanlı, Safevi ve Hint-Timur topraklarında bozulma açıkça kendini gösterdi; olumlu bir durumun yaşandığı yerlerde ise bu yenidünya güçlerinin birer eseri oldu. ...Yüzyılın sonuna gelindiğinde islam dünyasının toplumsal yapısında birikmiş olan gerilimler, Batı'nın dünya egemenliğini kurmasını takip eden yeni radikal düzenlemelerin yapılmasını zorunlu hale getirdi." ${ }^{89}$

\section{Sonuç}

Batı merkezli uygarlığın oluşturduğu simgesel davranışlar, imgeler ve söylemler geniş ölçekte tarihsel değişim hızını siyasi, ekonomik ve kültürel olarak dünyayı etkileyebilecek şekilde kurgulandığı açıktır. Bir

\footnotetext{
87 Hodgson, a.g.e., s. 153.

88 Hodgson, a.g.e., s. 121.

89 Marshall G.S. Hodgson, İslam'ın Serüveni: Barut imparatorlukları ve Modern Zamanlar, C. 3, çev. Berkay

Ersöz, Ankara, 2017, s. 169.
}

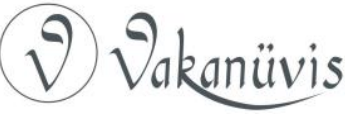


bakıma Avrupamerkezcilik, geçmiş tarihin ve günümüzün yeni tarih yaratma aktivitelerinin somut olarak çalışması ile oluşmaktadır. Tarihin coğrafi bölgelere ve tarihi dönemlere bölünmesi bilimsel olgu sorunu değildir. Aydınlatıcı olduğu ölçüde yanıltıcı olabilecek tarafıyla da yoruma açık bir varsayım ya da düşünce aracıdır. Tarihte bu sorun bir ölçüde "hegemonya" uygulamalarında ortaya çıkan girişimlerin "ilerici" ve "gerici" karşılaştırmalı kavramların çözümlemesinden ibarettir.

Tarihi uygarlıkların doğuş, yükseliş ve çöküş denklemi içinde geçen hayat döngüsünün var olması her türlü ilerlemenin "zaman-mekân" dâhilinde kesinlikle sürekli olmadığı varsayımı tartışmaya açık bir sorundur. "ilerleme" soyut bir kavram olarak Batı aklının gücüyle toplum özgürlügünü ve refahını kategorize etmek için kullanılmaktadır. Çizgisel tarih fikriyle özdeşleştirilen "ilerleme" kavramı, Batı üstünlüğünü doğrulamak için bilim ve teknolojiyi belirli bir amaca doğru yöneltmektedir. Bilimle teknolojinin tarihi sürece kazandırdığı "hegemonya" olgusu tutarlı bir şekilde dünya tarihi bağlamına yerleştirilmeye çalışılmaktadır. Çünkü Batı'ya özgü olan "ilerleme" sürecinin diğer toplumlarda yaşanmamasının nedenleri ve eşzamanlı olarak Batı-dışı toplumlarda yaşanan "çöküşün" yarattığı karmaşık bir görüntünün sonuçlarıyla izah etmek sosyal bilimsellik açısından önemlidir.

Batı hegemonyasının Avrupalı kimliğini yeniden tanımlaması için aleni şekilde sömürgeciliğe yönelen özellikleri rasyonel idarecilik yetileriyle değerlendirilmelidir. Ortaçağ'dan başlayan Doğu'ya karşı olumsuz eğilimlerle Avrupa'nın kurgulamaya çalıştığı kimlik oluşturma projesi arasındaki diyalektik göründüğü kadar yüzeysel değildir. Bu noktada Aydınlanma'nın "güç" olma ayrıcalı̆̆ını nesnellik açısından görmek ilginçtir. Sürece geniş açıdan bakarsak gerçeklik bilgisine ulaşmak mümkündür. Bir başka deyişle, Doğu ve başta İslam toplumlarına ait kaynakların asimle edilmesi ya da yeniden kurgulanması Batı dünyasının gelişiminde belirleyici olduğu açıktır. Doğu kaynaklarının (düşünce, kurumlar ve teknoloji) 500 - 1800 yılları arasında geri kalmış Batı'ya doğru taşınması İslami köprü üzerinden gerçekleştirilmektedir. Bu tez "dünya tarihi bütünlük" konseptinin temel problematikası olarak Batı hamlelerinden ne anlaşıldığını görmek açısından önemlidir.

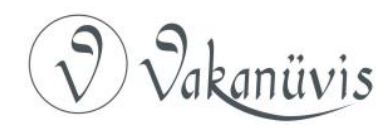


Modernitenin doğumuna sebebiyet vermiş büyük kırılmada şartlar ve entelektüel teşebbüsler yeni bir felsefi formasyon üzerinde yükselmektedir. Teknoloji yeniliğin getirdiği "düzenlilik, denetimlilik ve tektiplilik" yasaları "modernitenin" temsil ettiği hegemonya birikimidir. "Avrupamerkezci" görüşte Batı'nın yükselişini simgeleyen modernite olgusu iç dinamiklerin "akılcı yaratıcılığına" bağlanmaktadır. Ancak dünya tarihine bakıldığında modernitenin 19. yüzyıldan itibaren hegemonyaya dayanan emperyal-teritoryal merkezli dünya algıSı eşzamanlı bir şekilde "bilgi ve güç"ten kaynaklanan bir faaliyetin göstergesidir. İki yüzyıllık tarihi süre içinde dünyada yaşanan Batı merkezli yıkımlar (Doğu’ya yönelik sömürü hareketleri, I. Dünya Savaşı ve II. Dünya Savaşı) Avrupamerkezciliğin küre çapındaki rolünün kavranabilmesi açısından önemli ipuçları vermektedir.

Bu zemin üzerinde somutlaşan kavram ise "ulus-devlet" modelidir. 19. yüzyılda modern devletin tarih sahnesine çıkışı ile Avrupamerkezciliğe özgü "ulus-devlet" tanımı yeni tarihsel gerçekliğin temelini oluşturmaktadır. Uluslar, etnikler, ailesel yapılar, dilsel ve dinsel farklılıkları bu model içinde yeniden kurgulanmaktadır. Görünüşteki bu çeşitliliğin altında yatan temel eksen iç dinamikler ile dış dinamikler arasındaki diyalektik ilişkilerin modernleşme açısından somutluk kazanmasıdır. Bu ilişkilerden doğan siyasal-ideolojik üstyapı (ulus-devlet olgusu) Aydınlanma felsefesinin zihinsel ürünüdür. Diğer eksende ise ekonomik formasyonun temelini oluşturan üretim ilişkileri ile üretici (kapitalizm sistemi) güçleri arasındaki diyalektik açığa çıkmaktadır.

\section{Kaynaklar}

Adorno, Theodor W. - Horkheimer, Max, Aydınlanmanın Diyalektiği, Çev. Nihat Ülner - Elif Öztarhan Karadoğan. İstanbul, 2014, Kabalcı Yay.

Ağaoğulları, Mehmet Ali (ed.), Sokrates'ten Jakobenlere: Batı'da Siyasal Düşünceler, İstanbul, 2015, iletişim Yay.

Alatlı, Alev, Batı'ya Yön Veren Metinler Kökler/Orta Çağlar ( $\infty$-1350), C. 1. İstanbul, 2010, Melisa Matbaacılık.

Amin, Samir, Avrupamerkezcilik: Bir Ideolojinin Eleştirisi, Çev. Mehmet Sert. İstanbul, 2007, Chiviyazılar Yay.

Anderson, Perry, Gramsci Hegemonya: Doğu/Batı Sorunu ve Strateji, Çev.

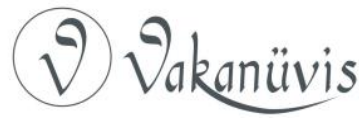


Tarık Günersel. İstanbul, 1988, Alan Yay.

Buttigieg, Joseph A. (Ed.), Antonio Gramsci: Hapishane Defterleri, C. 1. Çev. Ekrem Ekici. İstanbul, 2011, Kalkedon Yay.

Buttigieg, Joseph A. (Ed.), Antonio Gramsci: Hapishane Defterleri, C. 2. Çev. Barış Baysal. İstanbul, 2012, Kalkedon Yay.

Buttigieg, Joseph A. (Ed.), Antonio Gramsci: Hapishane Defterleri, C. 3. Çev. Barış Baysal. İstanbul, 2012, Kalkedon Yay

Buttigieg, Joseph A. (Ed.), Antonio Gramsci: Hapishane Defterleri, C. 4. Çev.Barış Baysal. İstanbul, 2014,Kalkedon Yay.

Carr, Edward Hallett, Tarih Nedir?, Çev. Misket Gizem Gürtürk. İstanbul, 2002, İletişim Yay.

Cevizci, Ahmet, Felsefe Sözlüğü, İstanbul, 2005, Paradigma Yay.

Copleston, Frederick, Felsefe Tarihi, C. 7. Çev. Aziz Yardımlı. İstanbul, 2004, İdea Yay.

Çiğdem, Ahmet, Aydınlanma Düşüncesi, İstanbul, 1993, Ağaç Yay.

Çiğdem, Ahmet, Bir Imkân Olarak Modernite: Weber ve Habermas, İstanbul, 1997, Illetişim Yay.

Foucault, Michel, Kelimeler ve Şeyler, Çev. Mehmet Ali Kılıçbay. İstanbul, 2001, İmge Kitabevi.

Foucault, Michel, Büyük Kapatılma, Çev. Işık Ergüden-Ferda Keskin. İstanbul, 2011, Ayrıntı Yay.

Foucault, Michel, Özne ve iktidar, Çev. Işık Ergüden-Osman Akınhay. İstanbul, 2014, Ayrıntı Yay.

Foucault, Michel, Bilginin Arkeolojisi, Çev. Veli Urhan. İstanbul, 2016, Birey Yay.

Giddens, Anthony, Sosyoloji, Çev. Zeynep Mercan. İstanbul, 2012, Kırmızı Yay.

Goody, Jack, Tarih Hırsızlığı, Çev. Gül Çağalı Güven. İstanbul, 2012, Türkiye İş Bankası Kültür Yay.

Gollingwood, Robin G.,Tarih Tasarımı, Çev. Kurtuluş Dinçer. İstanbul, 1990, Ara Yay.

Gramsci, Antonio, Hapishane Defterleri: Seçmeler, Çev. Kenan Somer. İstanbul, 1986, Onur Yay.

Hall, Stuart - Lumley, Bob - McLennan, Gregor, Siyaset ve Ideoloji: Gramsci, Çev. Sadun Emrealp. Ankara, 1985, Birey ve Toplum Yay.

Hegel, Georg Wilhelm Friedrich, Tarih Felsefesi, Çev. Aziz Yardımlı. İstanbul, 2006, İdea Yayınevi.

Herder, J. G. Another Philosophy of History and Selected Political Writings (I. D. Evrigenis ve D. Pellerin, Çev.). Indianapolis: Hackett, 2004.

Hobsbawm, Eric, Devrim Çağı: Avrupa 1789-1848, Çev. Bahadır Sina Şener. Ankara, 2003, Dost Kitabevi Yay.

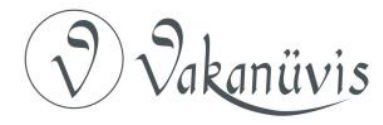


Hobson, John M., Batı Medeniyetinin Doğulu Kökenleri, Çev. Esra Ermert. İstanbul, 2015, Yapı Kredi Yay.

Hodgson, G.S. Marshall, Dünya Tarihini Yeniden Düşünmek, Çev. Ahemt Kanlıdere-Ahmet Aydoğan. İstanbul, 2017, Vadi Yay.

Hodgson, G.S. Marshall, İslam'ın Serüveni: Barut imparatorlukları ve Modern Zamanlar, C. 3. Çev. Berkay Ersöz. Ankara, 2017, Phoenix Yay.

İbni Haldun, Mukaddime, C. 1, çev. Turan Dursun. Ankara, 1977, Onur Yay.

İggers, Georg G., Bilimsel Nesnellikten Postmodernizme Yirminci Yüzyılda Tarih Yazımı, Çev. Gül Çağalı Güven. İstanbul, 2011, Tarih Vakfı Yurt Yay.

Marx, Karl - Engels, Friedrich, Alman Ideolojisi, çev. Olcay Geridönmez Tonguç Ok, İstanbul, 2018,

Merquior, Jose Guilherme, Foucault, Çev. Nurettin Elhüseyni. İstanbul, 1986, Afa Yay.

Nietzsche, Friedrich, Şen Bilim, Çev. Ahmet İnam. İstanbul, 2011, Say Yay.

Nietzsche, Friedrich, Deccal, Çev. Oruç Aruoba. İstanbul, 2000, Hil Yay.

Özlem, Doğan, Siyaset, Bilim ve Tarih Bilinci, İstanbul, 1999, İnkılap Yay.

Özlem, Doğan, Tarih Felsefesi, İstanbul, 2012, Notos Kitap Yay.

Russell, Bertrand, Batı Felsefesi Tarihi: Modern Çă̆-Yeni Çağ, C. 3. Çev. Muammer Sencer. Ankara, 1972, Bilgi Basımevi.

Said, Edward. Oryantalizm, Çev. Nezih Uzel. İstanbul, 1998, İrfan Yay.

Swingewood, Alan, Sosyolojik Düşüncenin Kısa Tarihi, Çev. Osman Akınhay. İstanbul, 1998, Bilim ve Sanat Yay.

Thomas, D. Peter, Gramsci Çağı: Felsefe - Hegemonya - Marksizm, Çev. ilker Akçay - Ekrem Ekici. Ankara, 2010,Dipnot Yay.

Turner, S. Bryan, Statü, Çev. Kemal İnal. Ankara, 2000, Doruk Yay.

Turner, S. Bryan, Oryantalizm, Postmodernizm ve Globalizm, Çev. Ibrahim Kapaklıkaya. İstanbul, 2003, Anka Yay.

Turner, S. Bryan, Marks ve Oryantalizmin Sonu, Çev. Çağatay Keskinok. Ankara, 1984, Kaynak Yay.

White, Hayden, Metatarih: Ondokuzuncu Yüzyıl Avrupası'da Tarihsel Imgelem, Çev. Mehmet Küçük. Ankara, 2008, Dost Kitabevi Yay. 